\title{
Effect of incorporation of walnut cake (Juglans regia) in concentrate mixture on degradation of dry matter, organic matter and production of microbial biomass in vitro in goat
}

\author{
Mohsin Ahmad Mir ${ }^{1}$, R. K. Sharma ${ }^{1}$, Ankur Rastogi ${ }^{1}$ and Keshab Barman ${ }^{2}$
}

1. Division of Animal Nutrition, Shere-e-Kashmir University of Agricultural Sciences and Technology of Jammu (J\&K), India; 2. Animal Nutrition Section, ICAR-NRC on Pig, Rani, Guwahati, Assam, India.

Corresponding author: Mohsin Ahmad Mir, e-mail: mr.mohsinmir@gmail.com, RKS: rksann@rediffmail.com, AR: dr_ankur76@rediffmail.com, KB: barman74@gmail.com

Received: 08-04-2015, Revised: 29-08-2015, Accepted: 06-09-2015, Published online: 09-10-2015

doi: 10.14202/vetworld.2015.1172-1176 How to cite this article: Mir MA, Sharma RK, Rastogi A, Barman K (2015) Effect of incorporation of walnut cake (Juglans regia) in concentrate mixture on degradation of dry matter, organic matter and production of microbial biomass in vitro in goat, Veterinary World 8(10): 1172-1176.

\begin{abstract}
Aim: This study was carried out to investigate the effect of incorporation of different level of walnut cake in concentrate mixture on in vitro dry matter degradation in order to determine its level of supplementation in ruminant ration.

Materials and Methods: Walnut cake was used @ 0, 10, 15, 20, 25 and 30\% level to formulate an iso-nitrogenous concentrate mixtures and designated as $\mathrm{T}_{1}, \mathrm{~T}_{2}, \mathrm{~T}_{3}, \mathrm{~T}_{4}, \mathrm{~T}_{5}$ and $\mathrm{T}_{6}$ respectively. The different formulae of concentrate mixtures were used for in vitro gas production studies using goat rumen liquor with wheat straw in 40:60 ratio. Proximate composition, fiber fractionation and calcium and phosphrous content of walnut cake were estimated.

Result: The per cent IVDMD value of T1 and T2 diets was $68.42 \pm 1.20$ and $67.25 \pm 1.37$ respectively which was found highest $(\mathrm{P}<0.05)$ T3, T4, T5 and T6. Similar trend was also found for TDOM and MBP. Inclusion of walnut cake at $10 \%$ level in the concentrate mixture does not affect in vitro dry matter digestibility (IVDMD), truly degradable organic matter (TDOM, mg/200 mg DM), total gas production, microbial biomass production (MBP) and efficiency of microbial biomass production (EMP).

Conclusion: It is concluded that walnut cake incorporation up to $10 \%$ level in the iso -nitrogenous concentrate mixture has no any negative effect on in vitro digestibility of dry matter (DM), TDOM, MBP, EMP and total gas production in goat.
\end{abstract}

Keywords: concentrate mixture, goat, in vitro dry matter digestibility, microbial biomass production, truly degradable organic matter, walnut cake.

\section{Introduction}

Chronic feed deficits represent a major constraint to animal production in many developing countries. The situation manifests itself in poor animal performance, low growth rates, reduced reproductive efficiency, high mortality rates, etc. The genetic potential of many farm animals is inadequately exploited and the output of animal production, such as meat, milk, eggs, fibre and skins, often fall far short of national requirements. A way out of this situation has been found in identifying, characterizing and promoting utilization of unconventional feedstuffs. Main advantage of feeding unconventional feedstuffs to livestock is to have less dependency on conventional feedstuffs, thereby sparing them for alternate use and reduction in cost of feeding $[1,2]$. One of such promising unconventional feed ingredient is walnut cake.

Jammu and Kashmir contributes around 98\% of the country's output and annually producing about 86,263 tonnes from an area of 61,723 hectares.

The worldwide production of walnuts has been increasing rapidly in recent years, with the largest

Copyright: The authors. This article is an open access article licensed under the terms of the Creative Commons Attributin License (http:// creative commons.org/licenses/by/2.0) which permits unrestricted use, distribution and reproduction in any medium, provided the work is properly cited. increase coming from Asia. The world produced a total of 2.55 million metric tonnes of walnuts in 2010 . At present, China is the world's largest producer of walnuts, with a total harvest of 1.06 million metric tonnes [3]. The other major producers of walnuts were (in the order of decreasing harvest): Iran (450,000 tonnes), United States (425,820 tonnes), Turkey (194,298 tonnes), Ukraine (96,900 tonnes), Mexico (110,605 tonnes), Romania (30,546 tonnes), India (40,000 tonnes), France (36,425 tonnes) and Chile (38,000 tonnes). The average worldwide walnut yield was about 3 metric tonnes per hectare, in 2010.

There are very few reports of the utilization of walnut cake/meal in livestock ration and it still remains an almost unstudied byproduct from the perspective of animal nutrition [4]. Utilization of walnut cake ruminant ration is not standardized. Hence, the present study has been carried out to find the level of incorporation of wall nut cake in ruminant ration using graded level in the ration in vitro using goat rumen liquor.

\section{Materials and Methods}

\section{Ethical approval}

This research was carried out after approval of Institutional Animal Ethics Committee of Sheree-Kashmir University of Agricultural Sciences and Technology of Jammu. 


\section{Source and processing of walnut cake}

Freshly expelled walnut cake was collected in gunny bags and brought to the laboratory. The cake was sundried, ground and stored for analysis. Proximate composition, fiber fractionation and calcium and phosphrous content of walnut cake were estimated. Iso-nitrogenous concentrate mixtures (Table-1) containing graded levels of walnut cake ( 0 - 30\% replacement) were formulated and subjected to in vitro gas production studies [5] using goat rumen liquor with concentrate: wheat straw at 40:60 ratio.

\section{Proximate analysis and fiber fractionation}

Proximate analysis of walnut cake sample was done as per AOAC [6] and fiber fractions [Neutral detergent fiber (NDF) and Acid detergent fiber (ADF)] were done as per standard method [7].

On the day of incubation, the mixture of rumen liquor and particulate matter (approximately 60:40) was collected from local slaughter house into prewarmed $\mathrm{CO}_{2}$ filled thermos and carried to the laboratory. The rumen fluid was bubbled with $\mathrm{CO}_{2}$ gas for few minutes and then mixed in a laboratory blender at medium speed to remove microbes attached to particulate matter. Rumen liquor was then strained through a double layer of muslin cloth. Strained liquor was then added to the buffer media (contains disodium hydrogen carbonate-9.8 g, sodium hydrogen phosphate $-9.3 \mathrm{~g}$, sodium chloride- $0.47 \mathrm{~g}$, potassium chloride-0.57 g, magnesium chloride-0.06 g per $1000 \mathrm{ml}$ distilled water with $\mathrm{pH}$ range of 6.7 to 6.8 ) when the media became colourless. Handling of rumen liquor was done under continuous flushing with $\mathrm{CO}_{2}$.

\section{Filling of syringes and incubation}

The buffered rumen fluid $(30 \mathrm{ml})$ was dispensed to each syringe containing $200 \mathrm{mg}$ sample by a marked self made dispenser. After recording initial volume $( \pm 0.5 \mathrm{ml})$, the syringes were placed in the incubator maintained at $39^{\circ} \mathrm{C}$. The syringes were shaken by hand intermittently at 3 hours interval. All incubations were run in triplicate and four syringes with buffered rumen fluid were incubated as blanks. A zero hour blank in duplicate was also kept during dispensing of buffered rumen fluid into syringes. Standard was also run in triplicate with wheat straw alone as incubated sample. At the end of incubation ( $24 \mathrm{~h}$ ) the amount of gas produced was measured by reading the position

Table-1: Ingredient composition (\%) of concentrate mixtures ( $w / w$, as such basis).

\begin{tabular}{lcccccc}
\hline Ingredients & $\mathbf{T}_{\mathbf{1}}$ & $\mathbf{T}_{\mathbf{2}}$ & $\mathbf{T}_{\mathbf{3}}$ & $\mathbf{T}_{\mathbf{4}}$ & $\mathbf{T}_{\mathbf{5}}$ & $\mathbf{T}_{\mathbf{6}}$ \\
\hline Maize & 30 & 25 & 22 & 20.5 & 18 & 15 \\
Wheat bran & 30 & 26 & 25 & 21.5 & 19.5 & 18 \\
Mustard cake & 37 & 36 & 35 & 35 & 34.5 & 34 \\
Walnut cake & - & 10 & 15 & 20 & 25 & 30 \\
Mineral mixture & 2 & 2 & 2 & 2 & 2 & 2 \\
Salt & 1 & 1 & 1 & 1 & 1 & 1 \\
\hline
\end{tabular}

$\mathrm{T}_{1}, \mathrm{~T}_{2}, \mathrm{~T}_{3}, \mathrm{~T}_{4}, \mathrm{~T}_{5}$ and $\mathrm{T}_{6}$ represent $0,10,15,20,25$ and $30 \%$ incorporation of walnut cake in the concentrate mixtures respectively of the plug and the contents of the syringes were analyzed further.

Determination of substrate degradation and microbial bio-mass production

The contents of the syringes were transferred to $500 \mathrm{ml}$ spoutless beakers by repeated washings with neutral detergent solution without sodium sulphite [7]. The contents were then refluxed for $1 \mathrm{~h}$ to extract the microbial matter from the undegraded feed [8] and the residue was recovered in pre-weighed sintered crucibles. After drying the crucibles (with residue) at $100^{\circ} \mathrm{C}$ to constant weight, ashing was done at $400^{\circ} \mathrm{C}$ to $500^{\circ} \mathrm{C}$ for $2 \mathrm{~h}$. In vitro dry matter degradability (IVDMD), Truly degradable organic matter (TDOM), microbial biomass production (MBP), efficiency of microbial biomass production (EMP) and Partition factor (PF) were calculated as follows:

$$
\begin{aligned}
& T D O M=\text { Feed }(O M) \text { incubated }- \text { residue }(O M) \\
& M B P=\text { TDOM }-(2.2 \times \text { net gas volume }) \\
& E M P=\{\text { TDOM }-(2.2 \times \text { net gas volume })\} \times 100 / \\
& \quad \text { TDOM } \\
& P F=\text { TDOM/net gas volume }
\end{aligned}
$$

\section{Statistical analysis}

Generalised linear model analysis of variance procedure was used for in vitro trial results and the means having significant difference were ranked as per Duncan's multiple range test [9].

\section{Results and Discussion}

\section{Proximate composition and fiber fractions of walnut cake}

The percent $\mathrm{OM}$ and CP were found to be 93.30 and 15.17, respectively. The NDF and ADF content of the walnut cake was $41.33 \%$ and $28.07 \%$, respectively. The CP content of concentrate mixture ranged from 17.57 in $\mathrm{T} 1$ to 18.14 in T6 and other fall within this range of variation (Table-2).

The moisture level of walnut cake recorded in the present study is well below 10-11\% level, making it safe for long term storage. Unlike other oil cakes routinely used for livestock feeding, the moderate CP content (15.17\%) and high crude fat content (12.15\%) of walnut cake make it similar in composition to grain byproducts like wheat or rice bran. However, the fibre content of walnut cake (41.33\% NDF and $28.07 \%$ $\mathrm{ADF})$ is much higher than most of the conventional concentrate supplements including brans. Similarly olive cake also contained high fiber content [10]. Further, unlike other concnetrate supplements, it is rich in calcium and poor in phosphorus leading to a metabolically distastrous calcium: Phosphorus ration of about $7: 1$.

The results of the present study are in contrast to most of the available mentions of chemical composition of walnut cake in referred literature [11-13]. The locally available walnut cake used in the present study is low in protein and phosphorus as compared to the previously reported composition and seems to be high in lignocellulose content although none of the 
Table-2: Proximate composition (mean $\pm \mathrm{SE}) *$ and fiber fractionation of concentrate mixture and walnut cake.

\begin{tabular}{lccccccc}
\hline Attribute & $\mathbf{T}_{\mathbf{1}}$ & $\mathbf{T}_{\mathbf{2}}$ & $\mathbf{T}_{\mathbf{3}}$ & $\mathbf{T}_{\mathbf{4}}$ & $\mathbf{T}_{\mathbf{5}}$ & $\mathbf{T}_{\mathbf{6}}$ & Walnut cake \\
\hline Moisture & $10.08 \pm 0.22$ & $9.91 \pm 0.25$ & $9.82 \pm 0.27$ & $9.74 \pm 0.28$ & $9.65 \pm 0.29$ & $9.57 \pm 0.30$ & $8.56 \pm 0.19$ \\
OM & $90.06 \pm 0.23$ & $90.11 \pm 0.18$ & $90.13 \pm 0.16$ & $90.16 \pm 0.13$ & $90.18 \pm 0.11$ & $90.20 \pm 0.09$ & $93.30 \pm 0.10$ \\
CP & $17.58 \pm 0.06$ & $17.69 \pm 0.09$ & $17.75 \pm 0.10$ & $17.90 \pm 0.11$ & $18.01 \pm 0.12$ & $18.14 \pm 0.14$ & $15.17 \pm 0.53$ \\
EE & $4.02 \pm 0.22$ & $4.86 \pm 0.19$ & $5.28 \pm 0.18$ & $5.69 \pm 0.17$ & $6.11 \pm 0.15$ & $6.53 \pm 0.14$ & $12.15 \pm 0.87$ \\
TA & $6.94 \pm 0.23$ & $6.89 \pm 0.18$ & $6.87 \pm 0.16$ & $6.84 \pm 0.13$ & $6.82 \pm 0.10$ & $6.80 \pm 0.08$ & $6.73 \pm 0.07$ \\
AIA & $2.47 \pm 0.05$ & $2.70 \pm 0.08$ & $2.83 \pm 0.10$ & $2.92 \pm 0.12$ & $3.04 \pm 0.13$ & $3.17 \pm 0.15$ & $2.93 \pm 0.07$ \\
NDF & $9.72 \pm 0.62$ & $12.88 \pm 0.50$ & $14.54 \pm 0.43$ & $15.98 \pm 0.37$ & $17.56 \pm 0.31$ & $19.20 \pm 0.25$ & $41.33 \pm 1.33$ \\
ADF & $23.47 \pm 0.08$ & $23.64 \pm 0.08$ & $24.11 \pm 0.08$ & $23.59 \pm 0.08$ & $23.68 \pm 0.08$ & $23.97 \pm 0.08$ & $28.07 \pm 0.67$ \\
Ca & - & - & - & - & - & - & $4.70 \pm 0.26$ \\
P & - & - & - & - & - & - & $0.66 \pm 0.01$ \\
\hline
\end{tabular}

*All values are means of sample analysis in triplicate and are on DM basis except moisture. OM=Organic matter, $\mathrm{CP}=$ Crude protein, $\mathrm{EE}=$ Ether extract, $\mathrm{TA}=$ Total ash, $\mathrm{AIA}=$ Acid insoluble ash, NDF=Neutral detergent fiber, $\mathrm{ADF}=\mathrm{Acid}$ detergent fiber, $\mathrm{Ca}=$ Calcium, $\mathrm{P}=$ Phosphorus, -=Not estimated, $\mathrm{T}_{1}, \mathrm{~T}_{2}, \mathrm{~T}_{3}, \mathrm{~T}_{4}, \mathrm{~T}_{5}$ and $\mathrm{T}_{6}$ represent $0,10,15,20,25$ and $30 \%$ incorporation of walnut cake in the concentrate mixtures respectively

previous studies have reported fibre fractions and the comparisons were made taking reported crude fibre content in consideration.

It has been reported that the main nutrients of walnut oil meal - protein, fat and fibre - are extremely variable: The nutritive value of walnut oil meal ranges between that of the high-energy walnut kernels (50-60\% oil) and the high fibre, low-energy shells. The nutritional value of walnut oil meal depends on the extraction process. The shells may or may not be removed prior to extraction, the kernels may or may not be toasted, there may be one or two mechanical pressing steps, cold or hot [4].

A French two-step process has been described as yielding two types of oil meals: The first pressing gives a relatively high fat $(20 \%)$ and medium protein $(32 \%)$ oil cake, whitish and containing kernel fragments, while the second pressing yields a darker (yellow-brown) product, containing less kernel particles, less oil (10-12\%) and more protein (37\%) [14] collected in France tend to support the notion that French walnut oil meals contain generally high levels of protein, low levels of fibre (5-10) (due to prior dehulling) and highly variable levels of oil (6-45\%).

American processes seem to yield products containing much less protein (13-17\%) and fat (6-10\%) and a high amount of fibre (crude fibre 27-33\%) [15-17]. It is reported by McGregor [15] that walnut meal contain twice the amount of fibre and half the protein, a composition barely more nutritious than that of walnut shells and it is this composition that was observed in the present study.

\section{In vitro degradation}

The composite ration comprising of different iso-nitrogenous concentrate mixtures containing variable levels of walnut cake $\left(\mathrm{L}_{10}, \mathrm{~L}_{15}, \mathrm{~L}_{20}, \mathrm{~L}_{25}\right.$ and $\mathrm{L}_{30}$ containing $10 \%, 15 \%, 20 \%, 25 \%$ and $30 \%$ of walnut cake, respectively) on a wheat straw based diet regimen was tested against control $\left(\mathrm{L}_{0}\right.$; conventional concentrate mixture) for in vitro dry matter degradation.

The per cent IVDMD of composite diet without the inclusion of walnut cake (control) was found to be highest at 68.42 , which was comparable to that of $\mathrm{L}_{10}(67.25)$ and was significantly higher $(\mathrm{P}<0.01)$ from IVDMD at other inclusion levels, which were similar to each other (Table-3). The trend was same with respect to TDOM (mg/200 $\mathrm{mg}$ DM) and MBP (mg/200 mg DM), although, no effect of walnut cake inclusion was observed on gas production $(\mathrm{ml} / 200 \mathrm{mg}$ DM), EMP (\% TDOM) and PF.

The composite ration comprising of different iso-nitrogenous concentrate mixtures containing variable levels of walnut cake on a wheat straw based diet regimen when tested against control via in vitro gas production study revealed that walnut cake is having a depressing effect over in vitro utilization of composite ration (Table-3), which becomes significant at 15\% or higher inclusion levels of walnut cake in concentrate mixture. The depressing effect was significant $(\mathrm{P}<0.01)$ with respect to TDOM $(\mathrm{mg} / 200 \mathrm{mg} \mathrm{DM})$ and MBP (mg/200 mg DM) and was not evident only in case of lowest supplementation level $\left(\mathrm{L}_{10}\right)$ tested in the present study.

The in vitro depression observed could be attributed to high fat and ADF content of the walnut cake. Goes et al.; Marcondes et al. [18,19] reported that OM digestibility is negatively correlated to high fiber content. It has been reported that walnut oil composition is dominated largely by unsaturated fatty acids (mainly linoleic together with lesser amounts of oleic and linolenic acids) along with minor proportions of tocopherols, phospholipids, sphingolipids, sterols, hydrocarbons and volatile compounds [20]. Further, it has been shown that high concentrations of free fatty acids in the rumen can alter digestion and appetite. It is well-known that high dietary levels of fats inhibit ruminal fermentation and thus diminish the utilization of dietary fiber [21-23]. It is also reported that [24] the fermentation pattern is affected by oil supplementation for concentrate-based diets.

Based on the results of in vitro trials, $\mathrm{L}_{10}$ ration with $10 \%$ inclusion level of walnut cake in composite ration (4\% level in composite ration) was the obvious and only available choice for the level to be tested through feeding trial. 
Table-3: In vitro dry matter degradation (mean \pm SE) of composite rations comprising of different concentrate mixtures containing variable levels of walnut cake with wheat straw in 40:60 ratio.

\begin{tabular}{|c|c|c|c|c|c|c|}
\hline Rations* & $\begin{array}{l}\text { IVDMD } \\
(\%)\end{array}$ & $\begin{array}{c}\text { TDOM } \\
(\mathrm{mg} / 200 \mathrm{mg} \mathrm{DM})\end{array}$ & $\begin{array}{l}\text { Gas production } \\
(\mathrm{ml} / 200 \mathrm{mgDM})\end{array}$ & $\begin{array}{c}\text { MBP } \\
(\mathrm{mg} / 200 \mathrm{mg} \mathrm{DM})\end{array}$ & $\begin{array}{c}\text { EMP } \\
\text { (\% TDOM) }\end{array}$ & PF \\
\hline $\begin{array}{l}\mathrm{L}_{0}\{(\text { Maize } 30 \%, \\
\text { WC } 0 \%, \text { MOC } 37 \% \text {, } \\
\text { WB } 30 \%) \text { ) } 40: \text { WS } 60\}\end{array}$ & $68.42^{\mathrm{a}} \pm 1.20$ & $132.13^{a} \pm 2.90$ & $18.83 \pm 2.22$ & $90.69^{a} \pm 5.50$ & $68.61 \pm 3.72$ & $7.60 \pm 1.03$ \\
\hline $\begin{array}{l}\mathrm{L}_{10}\{(\text { Maize } 25 \%, \\
\text { WC10\%, MOC } 36 \%, \\
\text { WB 26) } 40 \text { :WS } 60\}\end{array}$ & $67.25^{\mathrm{a}} \pm 1.37$ & $130.29^{\mathrm{a}} \pm 4.17$ & $19.5 \pm 1.55$ & $87.39^{\mathrm{a}} \pm 4.62$ & $67.02 \pm 2.45$ & $6.87 \pm 0.53$ \\
\hline $\begin{array}{l}\mathrm{L}_{15}\{(\text { Maize } 22 \%, \\
\text { WC15\%, MOC 35\%, } \\
\text { WB } 25 \%) 40 \text { : WS } 60\}\end{array}$ & $60.92^{b} \pm 2.26$ & $113.96^{b} \pm 4.09$ & $18.67 \pm 1.16$ & $72.89^{b} \pm 6.24$ & $63.43 \pm 3.28$ & $6.30 \pm 0.63$ \\
\hline $\begin{array}{l}\mathrm{L}_{20}\{(\text { Maize } 20.5 \%, \\
\text { WC } 20 \%, \text { MOC } 35 \%, \\
\text { WB } 21.5 \%) 40: \text { WS } 60\}\end{array}$ & $60.17^{\mathrm{b}} \pm 1.21$ & $117.68^{\mathrm{b}} \pm 1.33$ & $20.61 \pm 0.95$ & $72.34^{b} \pm 2.92$ & $61.40 \pm 2.04$ & $5.78 \pm 0.30$ \\
\hline $\begin{array}{l}\mathrm{L}_{25}\{(\text { Maize } 18 \% \\
\text { WC } 25 \%, \text { MOC } 34.5 \%, \\
\text { WB } 19.5 \%) 40: \text { WS } 60\}\end{array}$ & $60.25^{\mathrm{b}} \pm 1.43$ & $116.30^{b} \pm 3.06$ & $19.33 \pm 2.35$ & $73.76^{b} \pm 3.93$ & $63.68 \pm 3.72$ & $6.34 \pm 0.57$ \\
\hline $\begin{array}{l}\mathrm{L}_{30}\{(\text { Maize } 15 \%, \\
\text { WC } 30 \%, \text { MOC } 34 \%, \\
\text { WB } 18 \%) 40 \text { :WS } 60\}\end{array}$ & $60.58^{\mathrm{b}} \pm 1.01$ & $113.27^{b} \pm 3.97$ & $18.67 \pm 2.00$ & $72.21^{\mathrm{b}} \pm 4.13$ & $63.88 \pm 3.17$ & $6.31 \pm 0.51$ \\
\hline$p$ value & 0.000 & 0.010 & 0.970 & 0.018 & 0.618 & 0.454 \\
\hline
\end{tabular}

abMeans bearing different superscripts within a column differ significantly $(p \leq 0.01)$. $* W C=$ Walnut cake, MOC $=$ Mustard oil cake, WB $=$ Wheat bran, WS=Wheat straw, IVDMD =In vitro dry matter degradability, TDOM=Truly degradable organic matter, $\mathrm{MBP}=$ Microbial biomass production, $\mathrm{EMP}=$ Efficiency of microbial biomass production, $\mathrm{PF}=$ Partition factor

\section{Conclusion}

It can be concluded that walnut cake incorporation up to $10 \%$ level in the iso-nitrogenous concentrate mixture has no any negative effect on in vitro digestibility of DM, TDOM, MBP, EMP and total gas production in goat.

\section{Authors' Contribution}

RKS conceptualized the aim of this study, designed and supervised the experiment. MAM executed the experiments, carried out laboratory analysis of feed samples and conducted statistical analysis. AR and $\mathrm{KB}$ has drafted and revised the manuscript. All authors read and approved the final manuscript.

\section{Acknowledgments}

The authors acknowledge the facilities and financial support provided for the present study from Sher-e-Kashmir University of Agricultural Sciences and technology of Jammu, India.

\section{Competing Interests} interests.

The authors declare that they have no competing

\section{References}

1. Orskov, E. R. (1998) Feed evaluation with emphasis on fibrous roughages and fluctuating supply of nutrients. A Review. Small Ruminant Res., 28: 1-8.

2. Areghore, E. M. (2000) Chemical composition and nutritive value of some tropical byproduct feedstuff for small ruminants in vivo digestibility. Anim.Feed Sci.Technol., 85: 99-109.

3. FAOSTAT. 2012 Jump up production of Walnut with shell by countries. UN Food \& Agriculture Organization. 2012. Available from: Faostat.fao.org/site/384/default.aspx Accessed on 21-02-2015.

4. Heuzé, V., Tran, G., Hassoun, P. and Lebas, F. (2012)
Walnut (Juglans regia). Feedipedia.org. A programme by INRA, CIRAD, AFZ and FAO. http://www.feedipedia.org/ node/38 Accessed on 10-06-2015.

5. Menke. K.H. and Steingass, H. (1988) Estimation of the energetic feed value obtained from chemical analysis and in vitro gas production using rumen fluid. Anim.Res. Develop. 28: 180-238.

6. AOAC. (1995) Official Methods of Analysis. Association of Official Analytical Chemists, $16^{\text {th }}$ ed. Washington, DC., USA.

7. Van Soest, P.J., Robertson, J.B. and Lewis, B.A. (1991) Methods for dietary fibre, neutral detergent fibre and non-starch polysaccharides in relation to animal nutrition. J.Dairy Sci., 74: 3583-3597.

8. Blümmel, M., Makkar, H.P.S., and Becker K. (1997) In vitro gas production: A technique revisited. J. Anim.Physiol. Anim.Nutri., 77: 24-34.

9. Duncan, B.B. (1955) Multiple range and multiple ' $F$ ' test: Biometrics, 11: 1-42.

10. Ashraf A, Sharma RK and Rastogi A. (2013) Effect of lime treatment of olive meal on in vitro utilization of total mixed ration containing olive meal as partial maize replacer, Vet World 6(7):440-443, doi:10.5455/vetworld.2013.440-443.

11. AFZ Association Française de Zootechnie- French Association for Animal Production. (2011) Databank of animal Nutrition/French feed database. Available at: http://www.zootechnie.fr/banque-de-donnees-de-lalimentation-animale/tarifs-et-partenariat.html. Accessed on 08-06-2015.

12. Kneeland, J.A. (1958) Minor oilseeds and tree nut meals. In: Processed plant protein foodstuffs. New York, Academic Press.

13. Lyman, C.M., Kuiken, K.A.and Hale, F. (1956) Essential amino acid content of farm feeds. J. Agric.Food Chem., 4 (12): 1008-1010.

14. Heuze V., Tran, G., Hassoun, P. and Lebas F. (2015). Walnut (Juglans regia), Feedipedia, a programme by INRA, CIRAD, AFZ and FAO. http://www.feedipedia.org/ node/38, Accessed on 10-06-2015.

15. McGregor, C. A. (2000) Directory of feeds and feed ingredients. Hoard's Dairyman Books, W. D. Hoard and Sons Company.

16. Kratzer, F.H. and Vohra, P. (1974). Feeding value of walnut 
meal for turkey poults. California Agric., 28:15-15.

17. Kendall, P.T. and Holme, D.W. (1982) Studies on the digestibilities of soya bean products, cereals, cereal and plant by-products in diets of dogs. J. Sci. Food Agric., 33: 813-822.

18. Goes, R.H.T.B., Souza, K.A., Patussi, R.A.,Cornelio, T.C., Oliveira, E. R., Brabes, K. C. S., (2010) In situ ruminal degradability of crambe, sunflower and soybean seeds and their by-products in sheep feeding. Acta Sci. - Anim.Sci. Maringá, 32: 271-277

19. Marcondes, M.I., Valadares, S.D., Detmann, E., Valadares, R. F. D., Silva, L. F. C. E., Fonseca, M. A., 2009. Rumen degradation and intestinal digestibility of crude protein in feeds for cattle. Rev. Bras. Zootec., 38: 2247-2257

20. Martínez, M.L., Labuckas, D.O., Lamarque, A.L. and Maestri, D.M. (2010) Walnut (Juglans regia L.): genetic resources, chemistry, by-products. J. Sci. Food Agric., 90(12): 1959-1967.
21. Vafa, T.S., Naserian, A.A and Heravi Moussavi, A.R.,(2009). Effects of different levels of fish oil and canola oil on in vitro and in vivo nutrient digestibility. Res. J. Biol. Sci., 4: 1221-1226.

22. Hristov, A.N., Vander Pol, M., Agle M., Zaman S. and Schneider C. (2009). Effect of lauric acid and coconut oil on ruminal fermentation, digestion, ammonia losses from manure, and milk fatty acid composition in lactating cows. J. Dairy Sci., 92:5561-5582.

23. Khotsakdee J., Vasupen, K., Wongsuthavas S., Bureenok S., Alhaidary, A., Mohamed H.E., Beynen A.C. and Yuangklang C. (2010). Rumen fermentation and nutrient digestibility in goats fed a tallow-rich ration fortified with yeastv, Res.J.Biol.Sci.,5(3): 246-250

24. Vargas J.E., Andrés S Yáñez Ruiz., D.R. and López S. (2011). The effect of olive, sunflower or linseed oils on the fermentation pattern and methane production in the rumen simulating technique, Options Méditerranéennes, A, 99: 163-168.

$* * * * * * * *$ 